\title{
EVALUATION OF HYBRIDIZATION BETWEEN PANGASIUSDJAMBAL BLEEKER 1846 AND PANGASANODON HYPOPHTHALMUS (SAUVAGE 1878): BIOMETRIC CHARACTERIZATION AND GROWTH ANALYSIS
}

\author{
Rudhy Gustiano*) and Anang Hari Kristanto*)
}

\begin{abstract}
Possible use of pangasiid hybrids in aquaculture might generate potential impacts on wild populations. Therefore, rapid identification tools in the field such as growth rate are urgently needed. This study examines morphological characters and growth performance of $\mathrm{P}$. djambal and $\mathrm{P}$. hypophthalmus and their reciprocal hybrids. A detailed morphological study analysed 32 morphometric measurements and 5 meristic counts on hybrids of Pangasius djambal and P. hypophthalmus. Morphometric analysis and meristic counts showed that the reciprocal hybrids have intermediate characters except for gill rakers number which were lower than that of parental species. In general, the hybrids have tendency to be like P. hypophthalmus rather than P. djambal. The only typical character P. djambal appearing in hybrids is teeth shape, both vomerine and palatine. It was shown that the true hybrids have seven pelvic fin rays. Eight months of growth comparison in earthen ponds showed that the hybrids have a better performance for specific growth rate than the parental stock.
\end{abstract}

\section{KEYWORDS: genetic, hybridization, biometric, growth, Pangasiidae}

\section{INTRODUCTION}

There have been many breeding program efforts to increase aquaculture production such as interspecific cross-breeding in fish which may lead to hybrids with valuable characteristics for aquaculture (sterility, monosex population, heterosis or growth etc.). In contrast with the abundant literature on the hybridization in other cultured fish families, in particular cichlids, salmonids, cyprinids and ictalurids (for review see Sneed 1971; Moav 1976; Wohlfart and Hulata 1981; Chevassus 1979; 1983), reports on hybridization of Pangasiid catfish is rather scarce. Catfishes of the family Pangasiidae are of great economic importance in Southeast Asia region such as $P$. djambal in Indonesia (Legendre et al. 2000; Gustiano et al. 2003), P. bocourti in Vietnam (Hung et al. 1999) and P. hypophthalmus (senior of P. sutchi) (Tarnchalanukit 1986). Therefore, it was decided to evaluate the effect of hybrid vigor through artificial hybridization in Pangasiid catfishes.
Enzymatic system (protein total) allowed easy and quick differentiation of Pangasius djambal from P. hypophthalmus: allele 100 for locus Prot1 and allele 105 for locus prot2 for the first species, while allele 100 for Prot1; allele 100 and 150 for Prot2) (Legendre et al. 2000). However, there are no genetic data available for the hybrids so far. Hence, it is important to provide quick identification tools in the field since the possible use of these pangasiid hybrids in aquaculture faces the problem of potential impact such as, genetic deterioration on wild populations. Additionally identification tools will be useful to evaluate the growth performance of the hybrids. This study investigated biometrical characters and growth performance of $\mathrm{P}$. djambal and $\mathrm{P}$. hypophthalmus and their hybrids.

\section{MATERIALS AND METHODS}

Biometrics. The following specimens examined in biometric analysis are Pangasius djambal: 114 specimens, 142 to $635 \mathrm{~mm}$,

*) Research Institute for Freshwater Fisheries, Bogor, Indonesia 
collected from the main rivers in Java, Sumatra and Kalimantan in Indonesia. Pangasianodon hypophthalmus: 31 specimens, $147-630 \mathrm{~mm}$, originated from fish culture in Mekong River, Vietnam and fish culture in West Java in Indonesia. Specimens of $P$. djambal and $P$. hypophthalmus are deposited in the Museum Zoologicum Bogoriense (MZB), Cibinong, Indonesia and in the Muséum National d'Histoire Naturelle (MNHN), Paris, France. Hybrid of female P. djambal $x$ male P. hypophthalmus: 45 specimens, $133-490 \mathrm{~mm}$. Hybrid of male P. hypophthalmus $x$ female P. djambal: 45 specimens, $129-473 \mathrm{~mm}$.

All of the hybrid specimens were from artificial breeding performed at Research Institute for Freshwater Fisheries (RIFF) Station in Sukamandi, Indonesia. Specimens of $P$. djambal and P. hypophthalmus were identified following Gustiano (2003).

The following anatomical abbreviations are used: SL, standard length, HL, head length. Body length was measured using a one meter graduated ruler. Thirty two measurements were made using a dial calliper following Pouyaud et al. (1999). Three additional measurements were done: width of pectoral spine, measured at base of second dorsal spine; anterior width of snout, taken between the borders of anterior nostril; posterior width of snout, taken between the borders of posterior nostril. Five counts were noted: total number of gill rakers on the first branchial arch, number of dorsal, anal, pectoral and pelvic fin rays. Morphological observations include the shape of the swim bladder, the shape of palatine and vomerine tooth patches.

Growth. Pangasius djambal, Pangasianodon hypophthalmus and their reciprocal hybrid were examined for growth analysis. The growth comparison study were performed in a $200 \mathrm{~m}^{2}$ earthen pond at Research Institute for Freshwater Fisheries (RIFF) station in Sukamandi, Indonesia. Initial size of the fish was $30 \pm 2.0 \mathrm{gram}$. The stocking density was 100 fish per pond. The fish were fed $3 \%$ of total biomass daily using artificial feed containing $28 \%$ protein. During eight month rearing period, monthly random sampling was done on $20 \%$ of population and body weight measured.

Formula for the specific growth rate following Huisman (1976):

$$
S G R=\frac{\frac{\ln W_{t}}{\ln W_{o}} \times 100 \%}{t}
$$

$$
\begin{aligned}
& \text { SGR }=\text { Daily individual spesific growth }\left(\% \text { day }{ }^{-1}\right) \\
& \text { Wt }=\text { body weigth at the end of experiment }(\mathrm{g}) \\
& \text { Wo }=\text { initial body weight }(\mathrm{g}) \\
& \mathrm{t} \quad=\text { rearing period (day) }
\end{aligned}
$$

\section{RESULTS AND DISCUSSION}

A principal component analysis performed on the 235 specimens using the covariance matrix for 30 measurements enable to separate P. djambal, P. hypophthalmus and their hybrid Pangasius djambal was located on the positive sector of factor $2, P$. hypophthalmus was on the negative sector of factor 2 , and their hybrids were in between parental species (Fig. 1).

Factor loading revealed that the second component of PCA was defined by vomerine length, palatine width, mandibular barbell length, palatine length, post- ocular length, anal fin length, maxillary barbell length, caudal peduncle depth, anal fin height (in decreasing order of importance). Further analysis showed that P. djambal differs from P. hypophthalmus by having a longer vomerine length (3.8 - 14\% $\mathrm{HL}$ Vs $0.6-2.5 \% \mathrm{HL}$ ) and a larger palatine width (1.9-8.8\%L Vs $0.7-1.8 \%$ LL). While on hybrids, those two characters were intermediate, $1.2-9.4 \%$ H for vomerine length and $1.2-4 \%$ for palatine width. Morphometric analysis of the specimens demonstrated clearly the presence of two species as defined by Robert and Vidthayanon (1991); Vidthayanon (1993); and Gustiano (2003) as well as hybrids in between of them. This intermediate shape of hybrids suggest that the product of present hybridisation were "true" hybrids resulting from the fusions of both parents and not parthenogenesis as observed on general occasions in fish (Chevassus 1983). The important characters revealed from PCA of parental species and reciprocal hybrids are listed on Table 1.

Based on the morphometric data, even though the reciprocal hybrids have intermediate characters, in general their morphology were relatively hypophthal mus- like except the teeth (vomerine and palatine) that was relatively djambal- like. Plot of the second principal component (factor 2 ) referring to standard 


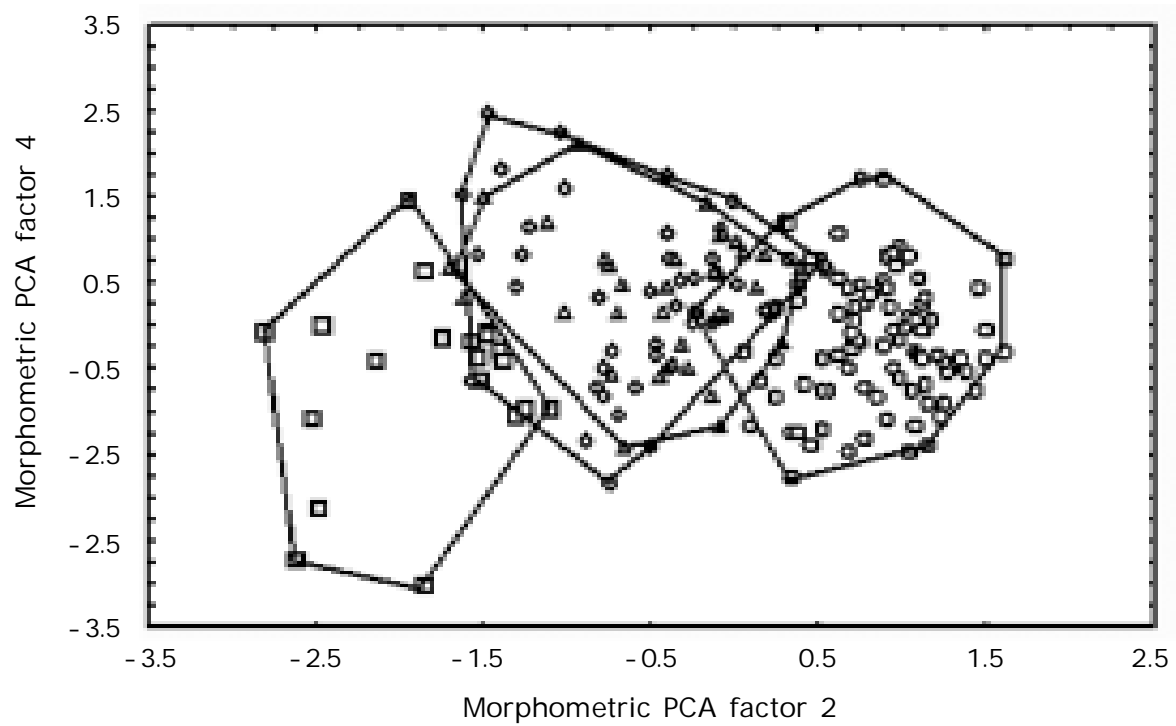

Figure 1. Plot of the second principal component (factor 2) versus the fourth principal component (factor 4) taken from a principal component analysis of 30 metric measurements on 245 specimens. \pm Pangasius djambal; 9 P. hypophthalmus; " P. hypophthalmus x P. djambal; $\triangle$ P. djambal x P. hypophthalmus

length (Fig. 2) supported this phenomena in which the tendency of importance character of hybrids was similar to that of $P$. hypophtalmus. Figure 2 also showed that the overlap between hybrids and parental species related to the size. For meristic observation, all of P. djambal had 6 pelvic fin ray, while there were 8 on P. hypophthalmus. Of the hybrids, more than $97 \%$ of hypophthalmus $x$ djambal had 7 pelvic fin rays. On the other side, the percentage was lower on the djambal $x$ hypophthalmus where it was about $17 \%$ of the hybrids had 6 or 8 pelvic fin rays. It is also clear that the true hybrids can be defined on the pelvic ray count. However, the case was contrary for gill raker number, the reciprocal hybrids had lower number than that of the parental species (Fig. 3). The gill raker number was probably due to the recessive evidence.

Based on the results of the present study, several characters enable separation between the hybrids and parental species, especially for pelvic fin rays. The results are very useful in providing a cheap and quick identification tool in the field rather than depending on other genetic analyses, such as enzymatic and DNA. Hence, the results from this study can also be used as a model to analyse other intergeneric hybridisation in which there is not much concern over homozygosity. Most of intergeneric hybridisation is successful under artificial breeding but in future studies should investigate the fertility of hybrids.

For the growth comparison among the different groups, average body weight during eight months rearing period is given on Table 2. At the end of experiment, the hybrids of female $P$. hypophthalmus $x$ male $P$. djambal reached $852.3 \mathrm{~g}$ body weight, followed by female P. djambal x male P. hypophthalmus (764.7 g), $P$. hypophthalmus $\times$ P. hypophthalmus (665.5 g), P. djambal x P. djambal (524.7 g).

Body weight is influenced by genetics, environmental variables (such as dissolved oxygen, temperature, feed etc.) and their interaction (Tave 1993). During the first six months of the study, dissolved oxygen concentration ranged between 3 to $6 \mathrm{ppm}$, and temperature was 26 to $31^{\circ} \mathrm{C}$. However, thereafter water quality became worse indicated by low response of feeding, colour and odour of the water in the ponds. To avoid further negative effects, the water in the bottom part was pumped out and then substituted by fresh water. Specific growth rate of the different group based on monthly sampling is shown in Table 3. 
Indonesian Aquaculture Journal Vol.2 No.1, 2007

Table 1. The important measured characters for specimens of P. djambal, P. hypophthalmus, and their reciprocal hybrids

\begin{tabular}{|c|c|c|c|c|}
\hline $\begin{array}{c}\% \text { Standard } \\
\text { length }\end{array}$ & P. jambal & P. hypoph. & $\begin{array}{c}\text { hypo x } \\
\text { jambal }\end{array}$ & $\begin{array}{c}\text { jambal } x \\
\text { hypo }\end{array}$ \\
\hline \multicolumn{5}{|c|}{ Caudal peduncle depth } \\
\hline $\mathrm{N}$ & 114 & 30 & 43 & 45 \\
\hline Mean & $8.18 \pm 0.59$ & $8.64 \pm 0.53$ & $9.00 \pm 0.53$ & $9.32 \pm 0.65$ \\
\hline Range & $6.70-10.60$ & $7.40-9.50$ & $7.67-10.05$ & $8.22-11.77$ \\
\hline \multicolumn{5}{|l|}{ Anal fin height } \\
\hline $\mathrm{N}$ & 110 & 30 & 45 & 45 \\
\hline Mean & $13.09 \pm 1.28$ & $14.86 \pm 1.39$ & $15.03 \pm 1.16$ & $13.80 \pm 1.30$ \\
\hline Range & $9.82-18.89$ & $11.99-18.25$ & $11.24-17.66$ & $9.93-16.24$ \\
\hline \multicolumn{5}{|l|}{ Anal fin length } \\
\hline $\mathrm{N}$ & 114 & 30 & 45 & 45 \\
\hline Mean & $27.53 \pm 1.80$ & $31.53 \pm 1.45$ & $32.14 \pm 1.51$ & $29.96 \pm 1.86$ \\
\hline Range & $23.78-39.27$ & 29.07-34.18 & $27.00-34.37$ & $22.27-32.91$ \\
\hline \multicolumn{5}{|c|}{$\%$ Head length } \\
\hline $\mathrm{N}$ & 112 & 29 & 45 & 45 \\
\hline Mean & $8.71 \pm 1.36$ & $10.72 \pm 0.85$ & $9.49 \pm 0.70$ & $9.95 \pm 0.83$ \\
\hline Range & $6.58-17.56$ & $9.74-14.32$ & $8.02-11.86$ & $7.92-11.65$ \\
\hline \multicolumn{5}{|c|}{ Maxillary barbel length } \\
\hline $\mathrm{N}$ & 108 & 26 & 45 & 45 \\
\hline Mean & $56.23 \pm 6.60$ & $38.79 \pm 10.61$ & $47.70 \pm 8.65$ & $49.56 \pm 13.03$ \\
\hline Range & $31.81-88.32$ & $21.95-57.16$ & $24.76-63.05$ & $21.10-67.44$ \\
\hline \multicolumn{5}{|c|}{ Mandibulary length } \\
\hline $\mathrm{N}$ & 109 & 25 & 45 & 42 \\
\hline Mean & $37.41 \pm 6.94$ & $20.80 \pm 8.66$ & $30.45 \pm 6.94$ & $29.48 \pm 9.05$ \\
\hline Range & $7.64-65.69$ & 7.11-33.91 & $18.33-44.56$ & $15.60-42.70$ \\
\hline \multicolumn{5}{|c|}{ Vomerine length } \\
\hline $\mathrm{N}$ & 113 & 27 & 45 & 45 \\
\hline Mean & $6.32 \pm 1.86$ & $1.40 \pm 0.39$ & $2.48 \pm 0.98$ & $2.89 \pm 1.33$ \\
\hline Range & $3.79-14.54$ & $0.61-2.50$ & $1.22-5.79$ & $1.46-9.38$ \\
\hline \multicolumn{5}{|l|}{ Palatine length } \\
\hline $\mathrm{N}$ & 113 & 25 & 45 & 45 \\
\hline Mean & $13.33 \pm 1.62$ & $7.81 \pm 1.51$ & $9.24 \pm 1.66$ & $9.70 \pm 1.59$ \\
\hline Range & 8.29-16.97 & $5.25-10.87$ & $6.06-13.14$ & $7.20-13.61$ \\
\hline \multicolumn{5}{|l|}{ Palatine width } \\
\hline $\mathrm{N}$ & 112 & 25 & 45 & 45 \\
\hline Mean & $3.94 \pm 0.89$ & $1.36 \pm 0.31$ & $2.25 \pm 0.49$ & $2.35 \pm 0.65$ \\
\hline Range & $1.94-8.76$ & $0.69-1.82$ & $1.45-3.31$ & $1.27-4.00$ \\
\hline
\end{tabular}

Table 3 shows normal phenomena in the fish growth such that young fish have a higher specific growth rate compared to the older fish. Among tested groups, the hybrids performed better specific growth rates after the six month rearing period in which the water quality deteriorated. This result indicates that there is a correlation with the genetic and environmental interaction factors. It is clearly defined that P. hypophthalmus is an air breathing catfish but not for P. djambal. Therefore, $P$. hypophthalmus is more adaptable to the poor water quality than P. djambal. Hybridization has improved performance of the hybrids compared to P. djambal indicating there is a gene from $P$. hypophthalmus transfered to the hybrids. Evenmore, the hybrids are better than both parental species. This study show similar 


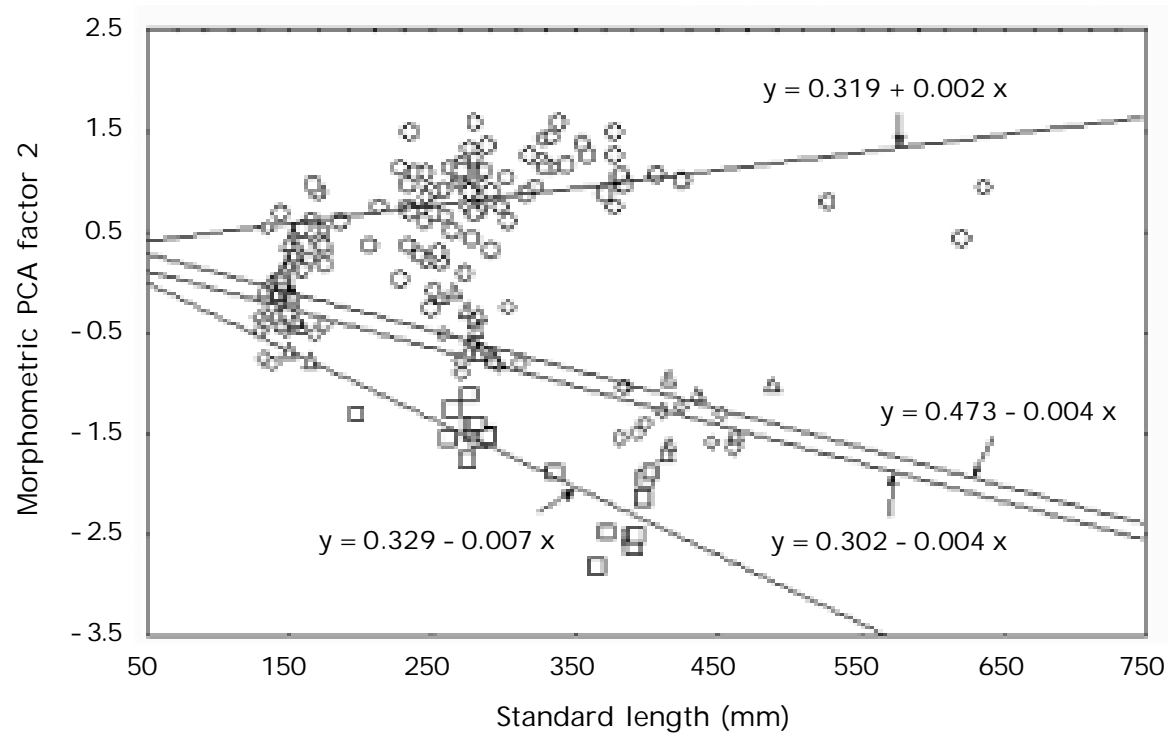

Figure 2. Plot of the second principal component (factor 2) referring to standard length of 235 specimens. \pm Pangasius djambal; 9 P. hypophthalmus; " P. hypophthalmus x P. djambal; $\triangle$ P. djambal x P. hypophthalmus

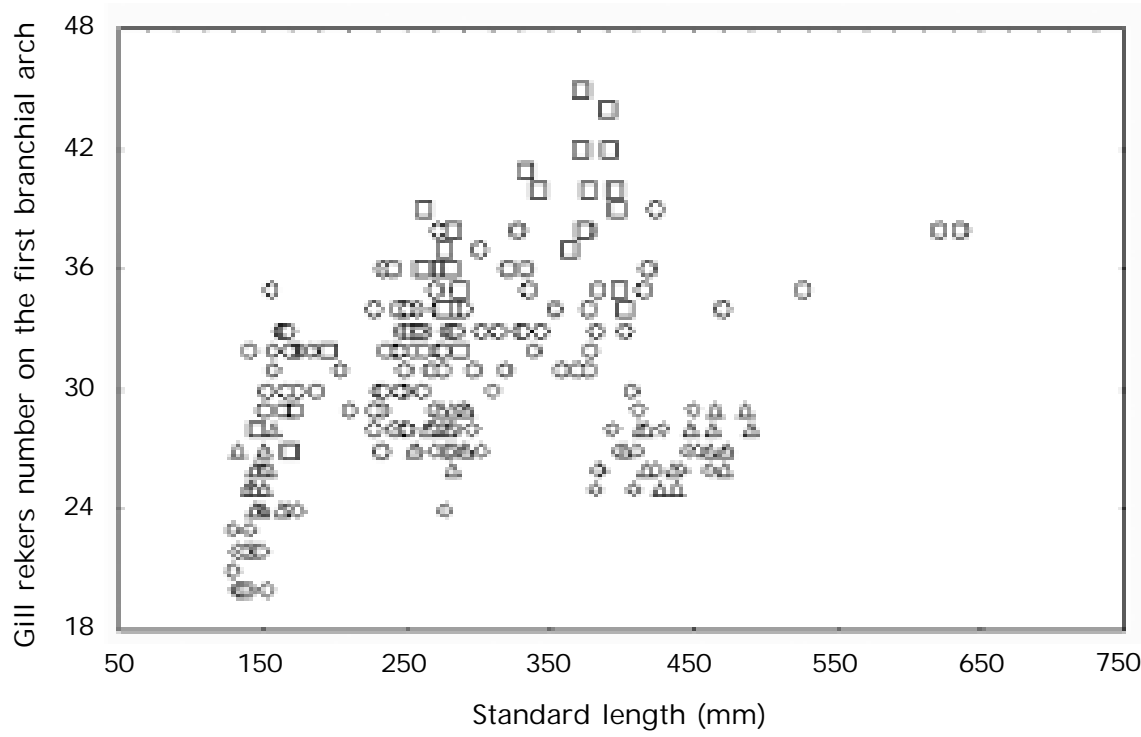

Figure 3. Scatter plot showing the gill raker number on the first branchial arch referring to standard length for \pm Pangasius djambal; $9 \mathrm{P}$. hypophthalmus; " P. hypophthalmus x P. djambal; $\triangle \mathrm{P}$. djambal $\times$ P. hypophthalmus 
Indonesian Aquaculture Journal Vol.2 No.1, 2007

Table 2. Average body weight (g) during eight month rearing period

\begin{tabular}{|c|c|c|c|c|}
\hline Rearing (m) & $\begin{array}{l}\text { o hypo x } \\
\text { t' hypo }\end{array}$ & $\begin{array}{c}\text { o djambal } x \\
\delta^{\pi} \text { hypo }\end{array}$ & $\begin{array}{l}\text { o djambal } x \\
\text { o djambal }\end{array}$ & $\begin{array}{c}\text { o hypo } x \\
\text { ot djambal }\end{array}$ \\
\hline Initial time & $30.0 \pm 2.00$ & $30.0 \pm 2.00$ & $30.0 \pm 2.00$ & $30.0, \pm 2.00$ \\
\hline 1 & $52.2 \pm 17.45$ & $167.5 \pm 24.58$ & $175.6 \pm 59.80$ & $125.4 \pm 12.31$ \\
\hline 2 & $124.1 \pm 34.03$ & $241.1+55.96$ & $254.1+52.89$ & $195.5+33.59$ \\
\hline 3 & $178.4 \pm 49.61$ & $332.2 \pm 72.45$ & $330.1 \pm 05.01$ & $254.6 \pm 38.72$ \\
\hline 4 & $310.0 \pm 94,87$ & $509.8 \pm 125.49$ & $496.5 \pm 160.63$ & $429.9 \pm 65.19$ \\
\hline 5 & $373.0 \pm 123.99$ & $550.8 \pm 102.45$ & $497.5 \pm 55.31$ & $497.7 \pm 79.66$ \\
\hline 6 & $418.3 \pm 131.27$ & $651.1 \pm 179.12$ & $439.4 \pm 152.92$ & $687.8 \pm 96.29$ \\
\hline 7 & $469.4 \pm 92.30$ & $672.6 \pm 169.80$ & $492.5 \pm 147.83$ & $752.6 \pm 135.27$ \\
\hline 8 & $665.5 \pm 128.13$ & $764.7 \pm 157.36$ & $524.7 \pm 151.96$ & $852.3 \pm 123.63$ \\
\hline
\end{tabular}

Table 3. Spesific growth rate ( $\%$ day) based on monthly sampling

\begin{tabular}{|c|c|c|c|c|}
\hline Month & $\begin{array}{l}\text { q hypo x } \\
\text { o hypo }\end{array}$ & $\begin{array}{c}\text { o djambal x } \\
\text { o hypo }\end{array}$ & $\begin{array}{l}\uparrow \text { djambal } x \\
\text { đ djambal }\end{array}$ & $\begin{array}{c}\text { } \text { hypo x } \\
\text { đ djambal }\end{array}$ \\
\hline 1 & 3.87 & 5.00 & 5.00 & 4.73 \\
\hline 2 & 2.36 & 2.68 & 2.71 & 2.58 \\
\hline 3 & 1.69 & 1.89 & 1.89 & 1.81 \\
\hline 4 & 1.40 & 1.55 & 1.52 & 1.48 \\
\hline 5 & 1.16 & 1.24 & 1.21 & 1.21 \\
\hline 6 & 0.98 & 1.05 & 0.99 & 1.06 \\
\hline 7 & 0.86 & 0.91 & 0.86 & 0.93 \\
\hline 8 & 0.79 & 0.81 & 0.76 & 0.82 \\
\hline
\end{tabular}

results to a study conducted in floating net cages using one month old fry for six weeks (Utami et al. 2005),

\section{CONCLUSION}

The reciprocal hybrids have intermediate characters, except lower number of gill rakers than that of parental species. It is clearly defined that the true hybrids have seven pelvic fin rays. The results of growth comparisons showed that hybrids have a better specific growth rate than that of parental species.

\section{REFERENCES}

Chevassus, B. 1979. Hybridization in salmonids results and perspective. Aquaculture $17: 113-128$.

Chevassus, B. 1983. Hybridization in fish. Aquaculture $33: 245-262$.
Gustiano, R. 2003. Taxonomy and Phylogeny of Pangasiidae catfishes from Asia. Ph.D Thesis, Leuven Univ., Belgium. 298 p.

Gustiano, R., Sudarto, L. Pouyaud. 2003. How to recognise Pangasius djambal?. In Technical Manual for Artificial Propagation of the Indonesian Catfish, Pangasius djambal (Editors: J. Slembrouck, O. Komarudin, Maskur, and L. Legendre). Karya Pratama, Jakarta. P: 3- 14.

Huisman, E.A. 1976. Food conversion efficiencies at maintenance and production levels for crap, cyprinus carpio L. And rainbow trout, Salmo gairdneri $R$. Aquaculture $9: 259-273$

Hung, L.T., B.M. Tam, P. Cacot and J. Lazard. 1999. Larval rearing of the Mekong catfish Pangasius bocourti (Pangasiidae, Siluridae) : Subtitution of Artemia nauplii with live and artificial feed. Aquat. Living 
Resour. 12 : 229-232.

Legendre, M., L. Pouyaud, J. Slembrouck, R. Gustiano, A.H. Kristanto, J. Subagya, O. Komarudin, Sudarto and Maskur. 2000. Pangasius djambal: A new candidate species for fish culture in Indonesia. IARD Journal 22: 1- 14.

Moav, R. 1976. Genetic improvement in the aquaculture industry. FAO Tech. Conf. On Aquaculture. Japan. FIR : Aq/Conf/76 : R.9.

Pouyaud, L., G.G. Teugels and M. Legendre. 1999. Description of new pangasiid catfish from south- East Asia (Siluriformes). Cybium 23: 247- 258.

Roberts. T.R. and C. Vidthayanon. 1991. Systematic revision of the Asian catfish family Pangasiidae with biological observation and description of three new species. Proc. Acad. Nat. Sci. Philad. 143: 97- 144.

Sneed, K.E.1971. Some current North American work in hybridization and selection of cultured fish. Report FAO/UNDP (TA) 2926 : 143- 150.

Tarnchalanukit, W.1986. Experimental hybridization between catfishes of families Clariidae and Pangasiidae in Thailand. Environ. Biol. Fish. 16: 317- 320.

Tave, D. 1993. Genetics for Fish Hatchery managers. AVI Publ. Comp. Inc, NY, USA $2^{\text {nd }}$ ed., 418 p.

Utami, R., B. Gunadi, D. Ariyanto and Sularto. 2005. Performance of fingerling of Pangasius hypophthalmus, Pangasius djambal and their hybrids reared in net cages. Abstract presented at World Aquaculture Society 2005, Bali, Indonesia.

Wohlfart, G.W. and G.I. Hulata. 1981. Applied genetics of Tilapias. ICLARM Studies and Review Vol. 6. Manila : ICLARM.

Vidthayanon, C. 1993. Taxonomic revision of catfish family Pangasiidae. Ph.D. Thesis. Tokyo University of Fisheries. 203 p. 